\title{
Opportunities for Renewable Energy Sources in Central Asia Countries
}

Alaibek J. Obozov

Project KUN

RECEIVED

Kyrgyzstan

JUL 201998

OSTI

Walter V. Loscutoff

NREL, U.S.A.

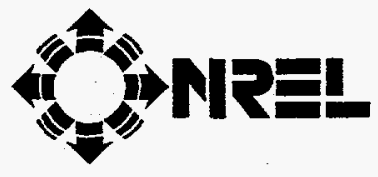

National Renewable Energy Laboratory

1617 Cole Boulevard

Golden, Colorado 80401-3393

A national laboratory of

the U.S. Department of Energy

Managed by Midwest Research Institute

for the U.S. Department of Energy

under Contract No. DE-AC36-83CH10093

Prepared under Task No. DO063040

July 1998 


\section{NOTICE}

This report was prepared as an account of work sponsored by an agency of the United States government. Neither the United States government nor any agency thereof, nor any of their employees, makes any warranty, express or implied, or assumes any legal liability or responsibility for the accuracy, completeness, or usefulness of any information, apparatus, product, or process disclosed, or represents that its use would not infringe privately owned rights. Reference herein to any specific commercial product, process, or service By trade name, trademark, manufacturer, or otherwise does not necessarily constitute or imply its endorsement, recommendation, or favoring by the United States govemment or any agency thereof. The views and opinions of authors expressed herein do not necessarily state or reflect those of the United States government or any agency thereof.

Available to DOE and DOE contractors from:

Office of Scientific and Technical Information (OSTI)

P.O. Box 62

Oak Ridge, TN 37831

Prices available by calling (423) 576-8401

Available to the public from:

National Technical Information Service (NTIS)

U.S. Department of Commerce

5285 Port Royal Road

Springfield, VA 22161

(703) $487-4650$ 


\section{DISCLAIMER}

Portions of this document may be illegible electronic image products. Images are produced from the best available original document. 


\title{
Opportunities for Renewable Energy Sources in Central Asia Countries
}

by

\author{
Alaibek J. Obozov \\ Project KUN \\ Kyrgyzstan \\ and \\ Walter V. Loscutoff \\ National Renewable Energy Laboratory \\ U.S.A.
}

July 1998 
TABLE OF CONTENTS

$\begin{array}{lc} & \text { Page } \\ \text { SUMMARY } & 2 \\ \text { INTRODUCTION } & 3 \\ \text { STATE OF ENERGY IN CENTRAL ASIA COUNTRIES } & 3 \\ \text { Population and Territories } & 6 \\ \text { Economics } & 6 \\ \text { Energy Reserves } & 6 \\ \text { Energy Production } & 7 \\ \text { RENEWABLE ENERGY SOURCES } & 8 \\ \text { Wind Energy } & 9 \\ \text { Solar Energy } & 10 \\ \text { BiomasS Energy } & 10 \\ \text { Micro Hydropower Stations } & 11 \\ \text { BARRIERS TO DEVELOPMENT OF RENEWABLE } & \\ \text { ENERGY SOURCES } & 13 \\ \text { CONCLUSIONS } & 14 \\ \text { BIBLIOGRAPHY } & 15\end{array}$




\section{SUMMARY}

This report presents an overview of the state of conventional energy sources and the potential for development of renewable energy sources in the Central Asia countries of Kazakhstan, Uzbekistan, Kyrgyzstan, Turkmenistan, and Tadjikistan. The region has a population of about 50 million in an area of more than four million square kilometers. The per capita gross internal product is more than $\$ 2,500$, although the economy has been declining the past five years. The area has substantial coal, oil, uranium, and natural gas reserves, although they are not distributed equally among the five countries. Energy production is such that the countries do not have to rely heavily on imports. One of the problems in Central Asia is that the energy prices are substantially below the world prices. This is a factor in development of renewable energy sources.

There is a large potential for the development of renewable energy sources in the five countries of Central Asia. As a result, each country has taken steps to integrate renewable energy sources into their energy systems. Kyrgyzstan has established the state project "Kun" to coordinate the development of renewable energy sources. Kazakhstan has established a national policy focused on increasing use of renewable energy sources. Uzbekistan has passed the "Law on Energy Savings" with provisions for stimulating development of renewable energy sources. Turkmenistan is developing specialists in solar and wind energies.

The primary renewable energy resources available are wind in Kazakhstan, solar in the entire region, biomass in Kyrgyzstan, and micro-hydropower stations in Kazakhstan and Kyrgyzstan. All of these have the potential to provide a significant amount of the required energy for the region. However, all of the countries have an abundance of various renewable energy resources. To effectively use these resources, however, a number of barriers to their development and commercialization must be overcome. These include low prices of conventional energy sources, absence of legislative support, lack of financing for new technologies, and lack of awareness of renewable energy sources by the population. A number of specific actions are proposed to overcome these barriers. These include establishment of a Central Asia coordinating council for renewable energy, development of a regional renewable energy program, and setting up a number of large demonstration projects.

\section{NOTE}

Dr. Alaibek Obozov is the General Director of the Kyrgyzstan State Project "Kun." He has more than 15 years of experience in renewable energy. From 1983 until 1992, he headed the Renewable Energy Sources Laboratory for the National Academy of Sciences. In 1992, he was appointed to lead Project Kun for the Kyrgyz Republic. Dr. Obozov has published more than 80 scientific papers, written three books, and received seven patents. This report is based on a presentation made by Dr. Obozov at NREL in June 1998.

Kun (which means sun in Kyrgyz) was established in 1992 to coordinate and carry out scientific and technical activities for solar, wind, biogas and other alternative sources of energy. The overall objectives of Kun are (a) to develop a renewable energy strategy for the country, (b) to coordinate the renewable energy activities in various research and industrial establishments, (c) to assist the government in legislative work, and (d) to develop standards and set up testing and certification facilities. 


\section{A. INTRODUCTION}

When people understand the environmental consequences of their activities, the use of energy and its extraction with a minimum harm to the environment become top priority items. Renewable energy sources (RES) thus become important energy sources. However, increasing their share in the total energy picture is a problem.

At the present time, the situation is favorable for expanding the use of RES to solve technical, economic, political, and ecological problems in the world, due to:

- Decreasing world reserves of fossil fuels

- Uneven distribution of energy reserves

- Rapid growth of energy use in developing countries

- Global climate change caused by the greenhouse effect

- Degradation of the environment by fossil-fuel-combustion pollution.

These factors are very important to the development of RES in the Central Asia countries.

\section{B. STATE OF ENERGY IN CENTRAL. ASIA COUNTRIES}

In this section we present the potential conventional energy reserves of the five countries of Central Asia formed as a result of the disintegration of the Soviet Union. Kazakhstan, Uzbekistan, Kyrgyzstan, Tadjikistan, and Turkmenistan are shown in Figure 1. Geographic and climatic conditions for these countries are given in Table 1.

Because of the existing geopolitical situation and the economic potential, the five countries need to act quickly to develop and stabilize their economies and social-political elements. A stable energy supply and a stable energy system structure are essential for such economic development.

For the next decade, traditional emphasis on conventional fuel sources and hydroelectric energy will, without doubt, dominate the energy balance of Central Asia and allow the establishment of stable conditions needed for restructuring the countries' economies. There will remain, however, many energy production problems that might be better addressed by new approaches such as use of renewable energy other than hydroelectric power. Even though Central Asia's regional energy supply is relatively high on the macro-level, it has many problems on the micro-level, such as providing energy to small manufacturers and to populations in remote regions, that are common in developing countries. Thus, structural changes are necessary and are possible not only by preserving the direction of traditional sources of energy, but also by developing new, ecologically clean energy technologies. 


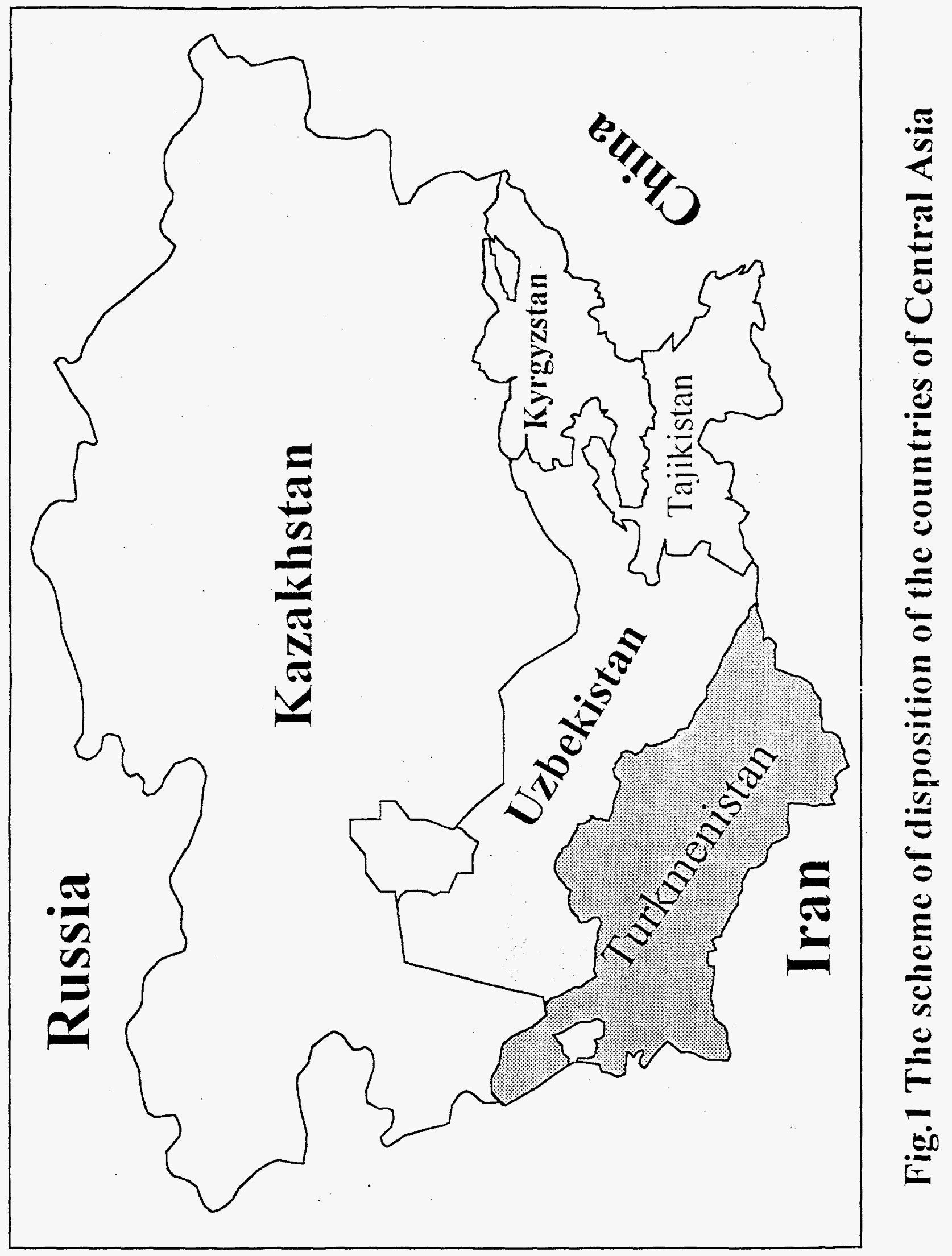


Tab.1 Geografhic and climatic conditions of the countries of Central Asia

\begin{tabular}{|c|c|c|c|c|c|}
\hline Characterislic & Kyrgyzstan & Karakhslan & Tajikistan & Turkmenislan & Uzbckistan \\
\hline Area, km12 & 198,500 & $2,717,300$ & $1+3,100$ & 488,100 & 447,400 \\
\hline $\begin{array}{ll}\text { Latitude } & \\
& \text { Northernmost } \\
& \text { Southernmost }\end{array}$ & $\begin{array}{l}43^{\circ} \mathrm{N} \\
39^{\circ} \mathrm{N}\end{array}$ & $\begin{array}{l}57^{\circ} \mathrm{N} \\
41^{\circ} \mathrm{N}\end{array}$ & $\begin{array}{l}41^{\circ} \mathrm{N} \\
37^{\circ} \mathrm{N}\end{array}$ & $\begin{array}{l}43^{\circ} \mathrm{N} \\
35^{\circ} \mathrm{N}\end{array}$ & $\begin{array}{l}46^{\circ} \mathrm{N} \\
37^{\circ} \mathrm{N}\end{array}$ \\
\hline Relief & $\begin{array}{l}\text { mountains (1,000-3000m), Alpine } \\
\text { lands, } \\
\text { glacial mountains }(3,000-4,500 \mathrm{~m}) \\
75 \% \text { of the country above } 1,500 \mathrm{~m} \\
94 \% \text { of the country above } 1,000 \mathrm{~m}\end{array}$ & $\begin{array}{l}\text { lowliands, vast plains } \\
\text { plate:ass, uplands, foothills, } \\
\text { moumtains, Alpine land about } \\
50 \% \text { desert of steppe }\end{array}$ & $\begin{array}{l}\text { mountiains }(1,00(1-4,000 \mathrm{~m}), \\
\text { Alpine lands, } \\
\text { glacial mountains } \\
(5,000-7,000 \mathrm{~m}), \\
\text { steam and broad valleys }\end{array}$ & $\begin{array}{l}\text { mooutains (1,000-3,000m), } \\
\text { footlill plains, uplands, } \\
\text { lowlands (Karakumy desert) }\end{array}$ & $\begin{array}{l}\text { about } 50 \% \text { llat to rolling sandy } \\
\text { desert or steppe; } \\
\text { Fergana Valley surrounded by } \\
\text { mountains }(1,000-2,500 \mathrm{~m}) \text {; some } \\
\text { Alpine lands and glacial plateaus, } \\
\text { some foothill plains }\end{array}$ \\
\hline $\begin{array}{rc}\text { Population } & \text { (1995) } \\
\text { Total, million } \\
\text { Rural population, \% } \\
\text { Population density; persons kim2 } \\
\text { dnmual gromth, \% p.a. }\end{array}$ & $\begin{array}{l}4,5 \\
65 \\
22.4 \\
0.5\end{array}$ & $\begin{array}{l}16,6 \\
4.4 \\
6.1 \\
0.1\end{array}$ & $\begin{array}{l}5,8 \\
72 \\
.10 .2 \\
1.9\end{array}$ & $\begin{array}{l}4,5 \\
55 \\
9.1 \\
4.1\end{array}$ & $\begin{array}{l}22,5 \\
61 \\
50.2 \\
2.1\end{array}$ \\
\hline Clinuate & $\begin{array}{l}\text { continental, low humidity great } \\
\text { diversity of weather }\end{array}$ & $\begin{array}{l}\text { continental (steppe, desert) will } \\
\text { pronounced zones }\end{array}$ & continenlal & continental arid & $\begin{array}{l}\text { extreme continental, parts sub } \\
\text { tropical }\end{array}$ \\
\hline $\begin{array}{r}\text { Temperatures, }\left({ }^{\circ} \mathrm{C}\right) \\
\text { Mean in Jan } \\
\text { Mean in July } \\
\text { Absolute minimum } \\
\text { Absolute maximum }\end{array}$ & $\begin{array}{l}-1.5 \text { to }-8 \text { (valleys) } \\
-20 \text { (highlands) } \\
+20 \text { to }+27 \text { (valleys) } \\
+5 \text { (highllands) } \\
-53 \text { (north) } \\
-34 \text { (south) } \\
+43 \text { (air) } \\
\end{array}$ & $\begin{array}{l}-18 \text { (north) } \\
-3 \text { (south) } \\
+19 \text { (not1h) } \\
+20 \text { to }+30(\text { south) } \\
-45 \text { (north) } \\
-35 \text { (south) } \\
\text { N/A } \\
\end{array}$ & $\begin{array}{l}-2 \text { (northem valleys) } \\
-20 \text { (SW mountains) } \\
+28 \text { (northem valley) } \\
+30 \text { (SW mountains) } \\
-63 \\
+48 \text { (air) }\end{array}$ & $\begin{array}{l}-4 \text { (north) } \\
+4 \text { (valleys) } \\
+28 \text { (norih east) } \\
+32 \text { (south) } \\
+49 \text { (desert) } \\
-32 \text { (north) } \\
-10 \text { (south) } \\
+70 \text { (Earth surface) }\end{array}$ & $\begin{array}{l}-8 \text { (Usturt Plateau,north) } \\
-3 \text { to }+3 \text { (south) } \\
+26 \text { (north) } \\
+32 \text { (south) } \\
+42 \text { (desert) } \\
-37 \text { (north) } \\
+70 \text { (Earth surface) } \\
\end{array}$ \\
\hline $\begin{array}{l}\text { Insolution } \\
\text { Vearli irradiation, } k W h / m 2 \text { yr } \\
\text { Ilours of stunshine, , hrs/yr }\end{array}$ & $\begin{array}{l}1500 \\
2600-2800\end{array}$ & $\begin{array}{l}1390-14.40 \\
2200-3000\end{array}$ & $\begin{array}{l}16,40-1690 \\
2600-3000\end{array}$ & $\begin{array}{l}1640-1830 \\
2.600-3000\end{array}$ & $\begin{array}{l}1640-1890 \\
2800-3000\end{array}$ \\
\hline Rainlitl, mm/yr & $\begin{array}{l}\text { 100-500 (hollows) } \\
180-250 \text { (Tjan-Shan) } \\
1.000 \text { (Fergana Range) }\end{array}$ & $\begin{array}{l}100 \text { (Ustutt Plateanti) } \\
300 \text { (noth) }\end{array}$ & $\begin{array}{l}150-30(0 \text { (plains) } \\
700 \text { (SW valley) } \\
1.600 \text { (Alpine lands) }\end{array}$ & $\begin{array}{l}80 \text { (north-eitst) } \\
150 \text { (desert) } \\
400 \text { (mountains) }\end{array}$ & $\begin{array}{l}90 \text { (plains) } \\
100 \text { (mountains) }\end{array}$ \\
\hline
\end{tabular}




\section{Populations and Territories}

The population of the Central Asia countries is more than 50 million. It consists mainly of Turk (Uzbek, Kazakh, Kirghiz and Turkmen) and Indoeuropean (Russian and Tadjik) ethnicities, but also includes immigrants from countries such as Korea, China, and Germany. Altogether, there are more than one hundred nationalities. The five countries occupy a total area of more than four million square kilometers. Population density varies among the countries but is relatively low throughout the region. It is determined by the geographic and economic conditions of the regions, and by the historic development of each region. Table 1 provides data on population, geographic characteristics, and climatic conditions for each country in Central Asia.

\section{Economies}

According to studies made by the World Bank, the gross internal products (GIP), of the five countries of Central Asia are comparable with those of developing countries and, as shown in Table 2, even match some of the "dynamic Asian economies" of Thailand (GIP of \$2105/person), Malaysia (GIP of $\$ 3242 /$ person), and Indonesia (GIP of $\$ 753 /$ person). However, this optimistic picture is not an accurate description of the economies of these countries today because the last five years have seen a steady decline in all aspects of their economies.

The economies of the Central Asia countries are dominated by extraction and processing of raw materials and by agriculture. In the past, these were oriented toward consumption within the borders of the Soviet Union. Today, the mining industry is experiencing a serious crisis because of the loss of traditional customers.

Table 2. Gross Internal Product of the Central Asia Countries (1994)

$\begin{array}{lcc}\text { Country } & \begin{array}{c}\text { GIP } \\ \text { (US\$ billion) }\end{array} & \begin{array}{c}\text { GIP/person } \\ \text { (US } \$ \text { ) }\end{array} \\ \text { Kazakhstan } & & \\ \text { Uzbekistan } & 55.20 & 3,258.17 \\ \text { Kyrgyzstan } & 54.50 & 2,455.84 \\ \text { Turkmenistan } & 8.40 & 1,882.14 \\ \text { Tadjikistan } & 13.10 & 3,003.90 \\ & 8.50 & 1,490.18\end{array}$

\section{Energy Reserves}

The Central Asian region has an abundance of mineral energy reserves. Known reserves of coal, gas and oil total 30 billion tons of oil equivalent (toe). These reserves are not, however, distributed homogeneously in the region. As Table 3 shows, nearly two-thirds of the total of energy reserves consist of coal in Kazakhstan. $70 \%$ of this is near the surface, so extraction is not expensive. Unfortunately, most of the coal is of low quality and has a high ash content. For example, the coal in the Turgai and Ekibastuz regions has low specific heat of combustion, 14.2 and $16.8 \mathrm{Mj} / \mathrm{kg}$, respectively. 
Table 3. Energy Reserves in the Central Asia Countries

$\begin{array}{lrrrr}\text { Country } & \begin{array}{c}\text { Coal } \\ \text { (Million toe) }\end{array} & \begin{array}{l}\text { Oil, condensate } \\ \text { (Million toe) }\end{array} & \begin{array}{c}\text { Natural gas } \\ \text { (Million toe) }\end{array} & \begin{array}{c}\text { Total } \\ \text { (Million toe) }\end{array} \\ \text { Kazakhstan } & 19,224.70 & 2,360.00 & 1,947.50 & 23,532.20 \\ \text { Uzbekistan } & 735.70 & 104.80 & 1,510.50 & 2,350.70 \\ \text { Kyrgyzstan } & 573.40 & 14.40 & 5.10 & 592.90 \\ \text { Turkmenistan } & 1.10 & 214.40 & 2,280.10 & 2,495.60 \\ \text { Tadjikistan } & 121.50 & 3.40 & 6.90 & 131.80 \\ \text { Total Central Asia } & 20,696.40 & 2,697.00 & 5,750.10 & 29,103.20\end{array}$

Figure 2 shows the primary energy reserves for each country as percent of total reserves in Central Asia. In addition, about $25 \%$ of the world reserves of uranium for nuclear energy are in Central Asia. About $80 \%$ of uranium extracted by the former Soviet Union came from Kazakhstan. Uranium is, undoubtedly, a strategic energy reserve of the region.

\section{Energy Production}

The production of energy from the various energy sources is shown in Figure 3. Table 4 shows the production, consumption, export, and import of the various forms of energy for the Central Asia countries.

Table 4. Production, Consumption, Export and Import of Energy Sources ( $k W h \times 10^{12}$ )

\begin{tabular}{|c|c|c|c|c|c|c|}
\hline & $\begin{array}{l}\text { Energy } \\
\text { Form }\end{array}$ & $\begin{array}{l}\text { Kazakh- } \\
\text { stan }\end{array}$ & $\begin{array}{l}\text { Uzbek- } \\
\text { istan }\end{array}$ & $\begin{array}{l}\text { Kyrgyz- } \\
\text { stan }\end{array}$ & $\begin{array}{l}\text { Turkmen- } \\
\text { istan }\end{array}$ & $\begin{array}{l}\text { Tadjik- } \\
\text { istan }\end{array}$ \\
\hline \multirow[t]{5}{*}{ Production } & Natural gas & 41 & 449 & 1 & 339 & - \\
\hline & Coal & 519 & 19 & 7 & - & - \\
\hline & Oil & 216 & 64 & 1 & 50 & 1 \\
\hline & Electricity & 16 & 19 & 13 & 2 & 17 \\
\hline & Others & 8 & 10 & - & 2 & - \\
\hline \multirow[t]{5}{*}{ Consumption } & Natural gas & 92 & 422 & 25 & 103 & 12 \\
\hline & Coal & 320 & 18 & 17 & - & - \\
\hline & Oil & 159 & 86 & 5 & 35 & 3 \\
\hline & Electricity & 42 & 13 & 11 & 6 & 15 \\
\hline & Others & 8 & 10 & - & 2 & - \\
\hline \multirow[t]{5}{*}{ Export } & Natural gas & - & 27 & - & 235 & - \\
\hline & Coal & 199 & - & - & - & - \\
\hline & Oil & 56 & - & - & 35 & - \\
\hline & Electricity & - & 6 & 3 & - & 2 \\
\hline & Others & - & - & - & - & - \\
\hline \multirow[t]{5}{*}{ Import } & Natural gas & 51 & - & 24 & - & 11 \\
\hline & Coal & - & - & 11 & - & - \\
\hline & Oil & - & 22 & 3 & 4 & 3 \\
\hline & Electricity & 26 & - & - & - & - \\
\hline & Others & & - & - & - & . \\
\hline
\end{tabular}


The energy infrastructures of the Central Asia countries were previously part of the total energy system of the former Soviet Union. The high degree of integration in the past resulted in strict dependence of the region on Russia, Ukraine, and other countries of the former Soviet Union for customers. Now, with changed relations with these countries, the five Central Asia countries no longer have secure markets for coal, oil, gas, uranium, and other products But the Central Asia countries do have a good base for supplying their own electrical power needs.

Figure 4 shows total power plant generating capacities, a combination of thermal power plants and hydropower plants.

The process of transition to a market economy focuses all currency and commodity resources to the stabilization of the financial structure. In fact, the energy complex is today's damper for softening the complications of the transition period. But the resulting absence of investment in the energy infrastructure has lead to a gradual deterioration of its elements.

In 1994, the Central Asia countries produced 155 billion kWh of electric energy while consuming 167 billion kWh. Production, imports, and exports by individual countries are given in Figure 5. In spite of the relatively high levels of production and consumption of electricity, there are regions without electricity, especially in remote rural regions. The greater portion of electricity is used in industry, mainly by mining and processing branches.

It is worthy to note that $90 \%$ of the electric power in Tadjikistan and $80 \%$ of the electric power in Kyrgyzstan are produced by hydroelectric stations. In Kazakhstan, the primary fuel for thermal power stations is coal. In Turkmenistan, only natural gas is used. Uzbekistan uses natural gas and black mineral oil. The only nuclear power station is located in Kazakhstan, in Akatu, and it also produces fresh water.

One of the significant parameters that define development and operation of energy infrastructure is the price of energy and its comparison with world prices. Figure 6 compares the energy prices in the Central Asia countries with the world market prices. As seen in the figure, the prices in Central Asia are far below world prices and even differ between the republics. This reflects upon the levels of efficiencies and importance placed on different kinds of energies.

\section{RENEWABLE ENERGY SOURCES}

Along with the development of the traditional energy infrastructure, the governments of the subject countries are seriously searching for other ways of expanding the infrastructure by looking at opportunities to use renewable energy sources (RES). This is associated with the national economic infrastructure and the following factors:

- $\quad$ Large potential of RES

- Unfavorable and deteriorating ecological situation

- $\quad$ Existence of sparsely populated areas far from grid lines

- Availability of technical staff and plants, including military, for conversion

- Experience in research, design, and construction at specialized institutions that allow construction of wind-power stations (WPS), micro-hydropower stations (MHPS) on mountain rivers, and solar systems for heat supply.

Some of the governments have already taken steps and are supporting integration of RES into the energy infrastructure.

To introduce new technologies using RES, Kyrgyzstan has established State Project "Kun" (Kyrgyz word for "sun") as an executive body of the Kyrgyz government. The objective of State Project "Kun" is to carry out and coordinate state energy policy in the use of RES. 
In Kazakhstan, the Ministry of Energy and Natural Resources established a state scientific and technical policy focused on increasing use of RES and the following organizations:

- Hydro energy reserves, based at the Institute "Almatyhydroproject"

- $\quad$ RES (sun, wind, biomass, and geothermal), at the Institute "Kazcelenergoproject"

- Determination of potential and construction of RES systems, at "Almatyenergo."

In Uzbekistan, the "Law on Energy Savings" was passed, with provisions for stimulating the development of practical RES systems. In the science area, PhysicaSun (Uzbekistan Academy of Sciences) operates the Unique Solar Furnace, with a capacity of $1 \mathrm{MW}$.

In Turkmenistan, specialists in the development of solar and wind energies for energy and water supply for small consumers in the desert regions work at the Desert Institute, Turkmenistan Academy of Sciences. Their appraisal is that the potential for RES in the region is very high.

\section{Wind Energy}

Kazakhstan is the leader in the region in terms of wind energy resources per person. The wind potential of the mountain pass to China, the Jungar Gates, by itself can provide about 1.3 trillion $\mathrm{kWh}$ of electric energy per year. Table 5 lists the potential of wind as an energy source in the main regions of Kazakhstan.

\section{Table 5. Wind Energy Resources in Kazakhstan (Preliminary Data from Almatyenergo)}

$\begin{array}{lcc}\text { Region } & \begin{array}{c}\text { Area } \\ \left(\mathrm{km}^{2} \times 10^{3}\right)\end{array} & \begin{array}{c}\text { Potential energy } \\ \left(\mathrm{kWh} / \mathrm{yr} \times 10^{9}\right)\end{array} \\ \text { East Kazakhstan } & 277.1 & 3000 \\ \text { South East } & 223.2 & 3100 \\ \text { South } & 499.9 & 5600 \\ \text { North } & 237.0 & 2700 \\ \text { Central } & 762.8 & 9100 \\ \text { West } & 729.2 & 8800 \\ \quad \text { Total } & 2718.1 & 32200\end{array}$

Usable wind power resources are estimated to be at 400 million $\mathrm{kw}$. For generating electricity for individual customers, the highest potential appears to be the use of small wind turbines with a capacity of $1-5 \mathrm{~kW}$. The construction of large wind turbines is the most likely prospect for villages and towns. According to Kazakh experts, the republic could be the number one country in the world in terms of wind resources per capita. A map of the distribution of mean wind speeds is given in Figure $\mathbf{1 4}$ for the Kyrgyz republic.

Figure 15 shows data on measurements of monthly amount of wind energy per $1 \mathrm{sq} . \mathrm{m}$. of area for one of the stations in Karaganda (Kazakhstan). The average output of three types of windmills is given for this location in Figure 16. From these diagrams, it is seen that the qualitative picture is same for all three systems. Quantitative differences are due to the differences in capacities of the three systems (Baigarin and de Boer, 1995). 


\section{Solar Energy}

One of the most promising renewable energy sources is solar energy. Data on average duration of solar insolation per year and total irradiation are given in Table 1 for Central Asia. The characteristics of insolation variation over a year are practically identical for the whole region and differ only in quantity. Figure $\mathbf{8}$ shows the variance in solar irradiation in four stations. Figure 9 shows the variance in solar irradiation on horizontal surfaces for several regions in Uzbekistan.

Figure 10 shows the savings in various fuel sources resulting from the use of solar water heating systems, based on a $1-\mathrm{m}^{2}$-solar collector. These are results of a mathematical model calculations of savings resulting from the use of solar energy as affected by various factors that include the kind of fuel being replaced, its heat capacity, cost, environmental impact and other parameters. The results require solving and optimizing a polyparametric problem.

Evaluation of the success in construction and use of solar heating systems shows that an important influence is the existence of government stimuli for enterprises, organizations, and consumers producing and using these installations. As seen in Figure 11, changes in price of consumed energy and government subsidies lead to considerable variation in the payback period for solar water heating systems. If the price of energy is increased from US\$.01/kWh to $\$ .03 / \mathrm{kWh}$, the payback period is reduced from 14 years to 2 years. If there is a $5 \%$ discount, the payback period is lowered to one year; if the government stimulus is higher, the period is just several months.

Therefore, for more effective implementation of solar facilities, it is necessary to strengthen legislation that provides favorable conditions. Natural tendency of growth in prices of traditional energy sources is a guarantee of increased prospects for solar energy systems.

\section{Biomass Energy}

One of the most abundant sources of renewable energy in Kyrgyzstan is biomass. Figure 12 shows calculated biomass reserves and their sources. From these sources, it is possible to obtain 1610 million $\mathrm{m}^{3}$ of methane gas. The calculations were made for methane obtained from wastes of stock bred in Kyrgyzstan. As shown by the histograms, active use of methane obtained from biomass provides substantial saving of organic fuels. In consumption of electricity, estimates show savings of more than 7.0 million MWh. Savings in heat energy are estimated at 6.72 million Gcal. Here is no information on the biomass reserves of the other Central Asia countries.

An additional benefit of biomass is environmental. The development of industry, intensive development of new mines, construction of big industrial complexes, and expanded use of modern technologies leads to the necessity of extraction of energy sources and consumption of energy. This intensifies pollution of the environment and may be hazardous to the ecology. An example of this is the damage done to the Aral Sea. Figure 7 shows the harmful emissions from the use of current sources of energy in Kyrgyzstan and the potential reduction in these emissions through the use of methane gas obtained from biomass. 


\section{Micro-Hydropower Stations}

The most interesting renewable energy sources are the small mountain watersheds. It is not only because of the presence of many mountain rivers, but also due to the large number of consumers situated in the mountainous areas, far from the central energy sources and who need energy for domestic and industrial purposes. These consumers are shepherds, farmers, forest rangers, bee masters, etc. There are more than 900 rivers in Kazakhstan alone, on which it is possible to construct a considerable number of micro-hydropower stations (MHPS).

The estimated potential of hydropower of small rivers (water flow rates of 0.7 to $50 \mathrm{~m}^{3} / \mathrm{s}$ ) in Kyrgyzstan is 7.0 billion $\mathrm{kWh} / \mathrm{yr}$. At the present time, only $2 \%$ of the potential hydropower has been developed. Numerous sources of irrigation water, rivers, and channels are not being utilized.

All operating MHPS were built in the 1929-1954 period and have been in operation 50-70 years without maintenance of equipment and components. To provide reliable equipment and increase efficiency of the hydropower systems, it is necessary to invest funds for repair and modernization of these stations. Table 6 gives main technical characteristics of operating MHPSs. There are MHPSs that are not in operation at present. Estimates of costs for repairs were made at some of them. Table 7 shows MHPSs that need repairs and Table 8 shows MHPSs under construction.

\section{Table 6. Main Technical Characteristics of Operating MHPS}

\begin{tabular}{lcccccr}
$\begin{array}{l}\text { Name of } \\
\text { HPS }\end{array}$ & $\begin{array}{c}\text { Year } \\
\text { built }\end{array}$ & $\begin{array}{c}\text { Capacity } \\
(\mathrm{MW})\end{array}$ & $\begin{array}{c}\text { Production } \\
(\mathrm{MkW}-\mathrm{h} / \mathrm{yr})\end{array}$ & $\begin{array}{c}\text { Number of } \\
\text { Turbines }\end{array}$ & $\begin{array}{c}\text { Water flow } \\
\text { thru turb. } \\
\left(\mathrm{m}^{3} / \mathrm{sec}\right)\end{array}$ & $\begin{array}{c}\text { Head } \\
(\mathrm{m})\end{array}$ \\
Lebedinovskaya & 1943 & 7.6 & 37.6 & 1 & 21.0 & 26.8 \\
& 1948 & & & 1 & 19.0 & \\
HPS-1 & 1945 & 2.2 & 5.7 & 2 & 12.5 & 11.8 \\
HPS-2 & 1948 & 2.5 & 7.8 & 2 & 15.0 & 12.3 \\
HPS-3 & 1950 & 2.1 & 5.8 & 2 & 11.7 & 10.8 \\
HPS-4 & 1952 & 2.1 & 5.9 & 2 & 11.7 & 10.8 \\
HPS-5 & 1957 & 6.4 & 8.4 & 2 & 25.0 & 15.2 \\
HPS-6 & 1957 & 6.4 & 6.9 & 2 & 25.0 & 15.2 \\
Malaya HPS & 1929 & 0.4 & 1.0 & 2 & 4.0 & 9.7 \\
Bystrovskaya & 1954 & 8.7 & 40.5 & 3 & 25.4 & 14.1 \\
\multicolumn{1}{c}{ TOTALS } & & 38.5 & 119.6 & 19 & &
\end{tabular}


Micro HPS requiring reconstruction

Table 7

\begin{tabular}{|c|c|c|c|c|c|c|c|}
\hline Name & $\begin{array}{l}\text { River, } \\
\text { channel }\end{array}$ & $\begin{array}{l}\text { Installed } \\
\text { capacityb } \\
\text { Mw }\end{array}$ & $\begin{array}{l}\text { Averagt } \\
\text { efficiency per } \\
\text { year } \\
\text { min kwill yr }\end{array}$ & Condition & $\begin{array}{l}\text { Working } \\
\text { head } \\
\text { cub.m/s } \\
\text { (m) }\end{array}$ & $\begin{array}{l}\text { Year } \\
\text { construc } \\
\text { tion }\end{array}$ & $\begin{array}{l}\text { Sum of } \\
\text { investitio } \\
\text { ns } \\
\text { min US } \\
\$\end{array}$ \\
\hline Kaliniskiaya & Kara-Balta & 1.48 & 5.26 & $\begin{array}{l}\text { does't operate } \\
\text { since } 1993 \\
\text { because of the } \\
\text { lanslide }\end{array}$ & & 1955 & 0.5 \\
\hline Sokuluk-2 & Sokuluk & 1.2 & 9.4 & $\begin{array}{l}\text { In1972 } \\
\text { conservated. The } \\
\text { main agregates } \\
\text { are destroyed. }\end{array}$ & & 1967 & 1.9 \\
\hline Jardv- Kaindy & Aspara & 0.44 & 3.1 & doesn't operate & & 1960 & 0.8 \\
\hline Arashan & AK-SuU & 1.9 & 12.2 & doesn't operate & $3(70)$ & 1961 & 2.9 \\
\hline Karakul-3 & Karakol & 1.5 & 10.8 & $\begin{array}{l}1967 \text { wrore } \\
\text { offand } \\
\text { demontaged }\end{array}$ & $3(63)$ & 1948 & 2.2 \\
\hline Karakul-4 & Karakol & 1.5 & 10.5 & doesn't operate & $3.0(60)$ & & 2.3 \\
\hline Juuku & Juuku & 0.8 & 5.6 & doesn t operate & $2(50)$ & & 1.5 \\
\hline Jetty-Oguz & Jetv-Oguz & 1.0 & 7.0 & doesn't operate & $2(60)$ & & 1.7 \\
\hline Chon-Kyzyl-Suu & $\begin{array}{l}\text { Chon- } \\
\text { Kvzwl-Suu }\end{array}$ & 1.2 & 8.2 & destroyed & $3(50)$ & 50-th & 2.2 \\
\hline Barskoun & Barskoon & 1.2 & 8.2 & destroyed & $2.5(60)$ & $50-$ th & 2.2 \\
\hline Tosor & Tosor & 0.4 & 4.1 & destroved & $1.5(50)$ & & 1.5 \\
\hline Turgen-Ak-Suu-1 & $\begin{array}{l}\text { Turgen-Ak- } \\
\text { Suu }\end{array}$ & 1.8 & 12.8 & destroyed & & & 2.1 \\
\hline Leninpolskava & Talas & 1.156 & 5.6 & doesn't operate & $3.5(23)$ & 1958 & 2.4 \\
\hline Kurk-hizyk & Talas & 0.74 & 2 & docsint operate & $2(24)$ & 1963 & 1.6 \\
\hline On-Arshiskaya & Naryn & 1.38 & 5.1 & doesn't operate & $1.6(35)$ & 1959 & 2.3 \\
\hline Issyk-Ala & lssyk-Ala & 1.5 & 5.4 & Goesn't uperate & & & 2.9 \\
\hline Sopu-Kurgon & Gulcha & 0.7 & 4.5 & doesn't operile & & & 1.5 \\
\hline Aravanskava & Aravan-Sai & 0.6 & 4.2 & dosisn toperille & & & 1.3 \\
\hline Tolal & & 20.496 & 123.96 & & & & 33.98 \\
\hline
\end{tabular}

Below in the table a set of projects of misio HPS recommended for construction in future.

Projects of construction micro hydro power stations

Table 8.

\begin{tabular}{|c|c|c|c|c|}
\hline Name & River chanuel & $\begin{array}{l}\text { Instalted capacity } \\
\text { Mu }\end{array}$ & $\begin{array}{l}\text { Average efliciency per } \\
\text { yr } \\
\text { wh kw h yr. }\end{array}$ & $\begin{array}{l}\text { Sum } \\
\text { investments } \\
\text { mln lis } 5\end{array}$ \\
\hline Karakol-1 & Karakol & $2 . t$ & 15.7 & 1.9 \\
\hline Karakol-2 & Karakol & 2.4 & 14.9 & 3.6 \\
\hline Kichinc-Kizvi-Suu & Kichine-Kuzvi-Suu & 0.6 & 4.1 & 1.3 \\
\hline Juukuchak & Juukuchak & 0.5 & 5.5 & 1.4 \\
\hline Chon-Jarkvicinak & Chon-jargy/hatk & 0.6 & 4.2 & 1.2 \\
\hline Irdik & Irdik & 0.6 & 4.1 & 1.3 \\
\hline Kensuu & Kensuu & 1.5 & 11.0 & 2.3 \\
\hline Chon-Tash & Chuntash & 2.0 & 13.7 & 2.5 \\
\hline Taldisuu & Taldycuu & 1.5 & 11.1 & 2.3 \\
\hline JyTgalan & Jyrgalan & 2.2 & 14.5 & 2.5 \\
\hline Bozuchuk & Bozuchuk & 1.5 & 11.2 & 2.0 \\
\hline Sandalash-1 & Chatkal & 12.0 & 72.0 & 14.6 \\
\hline Sandalash-2 & Chatkal & 13 & 75.0 & 15.8 \\
\hline Issuk-Ala-2 & Issyk-Ata & 1.5 & 13.8 & 2.8 \\
\hline Issvk -Aln-4 & Issyk-Ata & $1 . x$ & 13.6 & 2.8 \\
\hline Turgen-Aksuu-2 & Turgen-Aksuu & 1.2 & 7.2 & 1.9 \\
\hline Karkyra & Karkvra & 6.1 & 33.6 & 8.6 \\
\hline Chon-Kemin & Chon-Kenuin & 15.0 & 60.0 & 16.3 \\
\hline Oital & Oital & 12.2 & 48.0 & 14.8 \\
\hline Isswk-Ala3 & Issyk-Ata & 1.8 & 8.3 & 2.8 \\
\hline Orto-Tukoi & Chui & 21.0 & 47.3 & 22.9 \\
\hline Kirovstioe & Talas & 21.0 & 70.0 & 22.9 \\
\hline Total: & & 102 & 649.6 & $1+8.5$ \\
\hline
\end{tabular}


An estimate of the cost of using MHPS as individual and autonomous energy sources is compared to centralized systems in Figure 13. As seen in the diagram, the competitiveness of MHPS depends on the cost of producing electricity, the number of customers, and the distance from transmission lines for centralized systems. The cost of electricity falls as the number of customers increases and the distance from transmission lines falls. In the case of MHPS, there is no dependence on the distance or the number of customers. The calculations show that capital investment affects the costs. They show that if a capital investment of US $\$ 500 / \mathrm{kW}$ of installed capacity is made on MHPS, the cost of electricity is lower than in a centralized system if there are fewer than 20 customers and their distance is greater than $10 \mathrm{~km}$ from the grid.

\section{BARRIERS TO DEVELOPMENT OF RENEWABLE ENERGY SOURCES}

The foregoing analysis of the conditions and potential of using RES shows that RES can play a significant role in the fuel energy infrastructure of the Central Asia countries and will not only promote the solution of energy problems, but could also provide successful solutions to socio-ecological problems. Thus, it is extremely important today to pay serious attention to the development of this branch of energy and promote its environmentally clean technologies. However, there are a number of barriers that prevent greater utilization of RES in the Central Asia region:

- Very low prices of traditional fuel energy sources

- $\quad$ Absence of a legislative base to promote RES and lack of state support

- Absence of a united coordinating state body (except in Kyrgyzstan) responsible for RES development in each country

- Lack of finance and absence of investors interested in investing in these technologies

- Lack of information and a population that is not aware of the opportunities of RES.

Therefore, to realize greater implementation of RES, these barriers must be removed. A number of areas are involved including organizational, technical, and legislative. Some of the important specific actions that are necessary in order to accelerate the implementation of RES are the following:

- $\quad$ Set up a Central Asia coordinating center for RES

- Develop a regional RES program with participation of all republics in order to avoid duplication of effort and to define priorities for RES development in each republic

- Have the legislative bodies of each country adopt laws that stimulate RES development and utilization

- Train highly qualified staff in all RES fields; this should include training of students at universities

- Set up a number of large RES demonstration pilot projects

- $\quad$ Perform market research for the Central Asia region

- $\quad$ Promote RES to attract financial institutions and private investors for obtaining funding in economically vital RES projects. 


\section{F. CONCLUSIONS}

Analysis of conditions and prospects of RES development in Central Asian countries shows the following. The most important RES for Kazakhstan is wind energy. For Uzbekistan and Turkmenistan, it is solar energy; high temperature solar furnaces in Uzbekistan and solar heat for agriculture in Turkmenistan. Kyrgyzstan and Tadjikistan are mountainous republics which can use the energy of small mountain rivers. . The presence of two large plants in Kyrgyzstan that produce polycrystalline silicon and monocrystalline silicon make it attractive for projects related to production of photovoltaic cells.

However, the prevalence of specific RES technologies does not mean exclusion of other sources because the whole region has extensive renewable energy resources and could benefit from the use of all forms of RES. Because of existing barriers in Central Asia, the development and growth of RES in the countries of Central Asia may be best carried out as joint activities with the U.S.A. and interested organizations in the U.S.A. such as the National Renewable Energy Laboratory. 


\section{BIBLIOGRAPHY}

The material for this report was based on the sources listed below and the first author's own research.

Baigarin, K. and de Boer, Andre. Wind Energy Potential for Central Asia, Moscow, 1995

Baigarin, K. Energy Situation in the Countries of Central Asia, Moscow, 1996

Coordinating-Consulting Energy Group of Central Asian Countries, Utilization of Thermal Solar Energy, Tashkent, 1997

International Centre for Energy and Environmental Technology, The Potential for Solar Energy Technologies in Central Asia, Leipzig, 1997

Regional business meetings promoting RES development in Central Asia, Results of. Almaty, 1997

The World Bank, Kazakhstan and Kyrgyzstan-Opportunities for Renewable Energy Development, Report Number 16855KAZ, Washington, 1997

European Economic Commission, Proceedings of International Conference on Problems of Solar Energy Utilization, Tashkent, 1997 


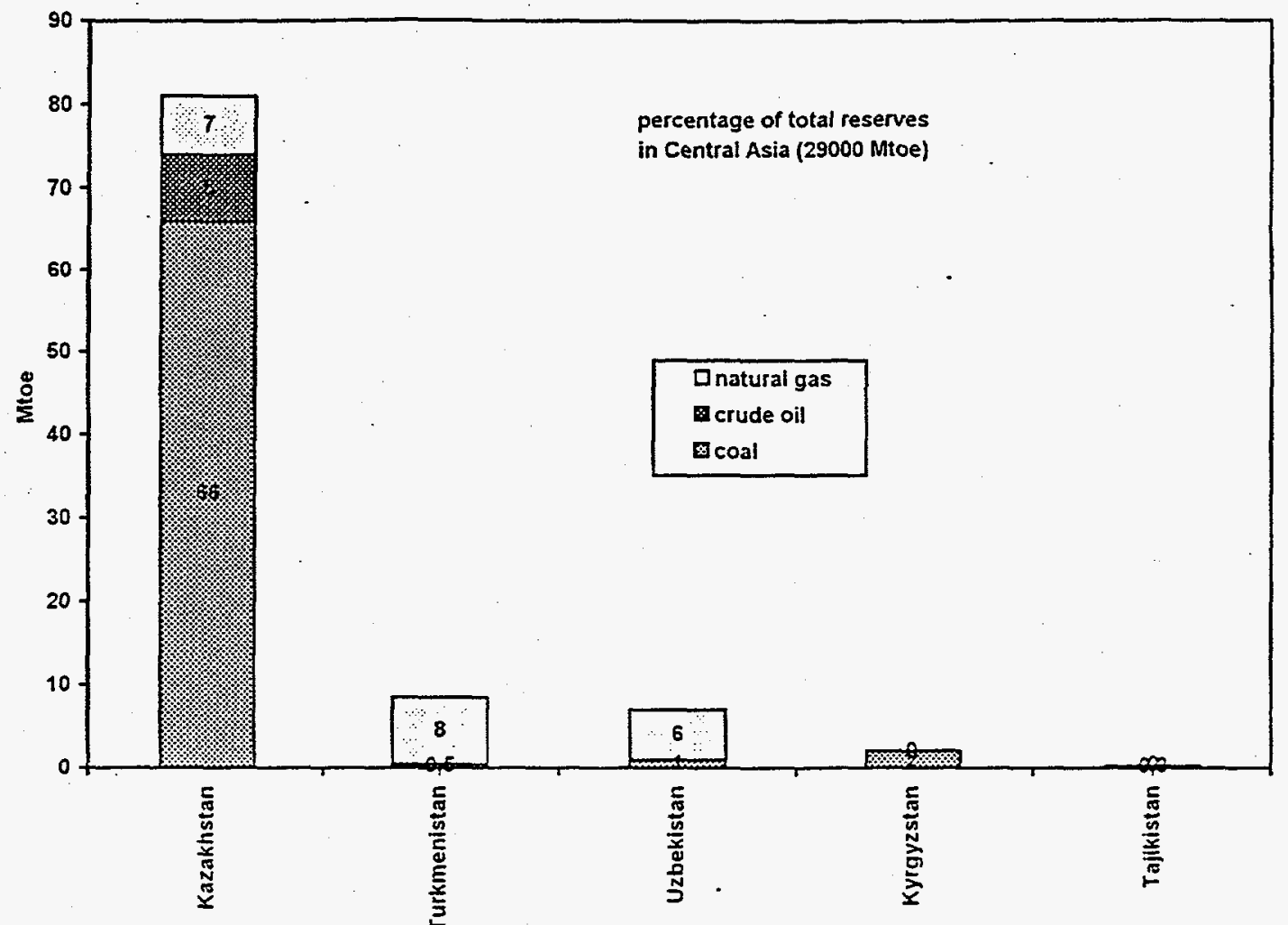

Fig.2 Primary Energy Reserves

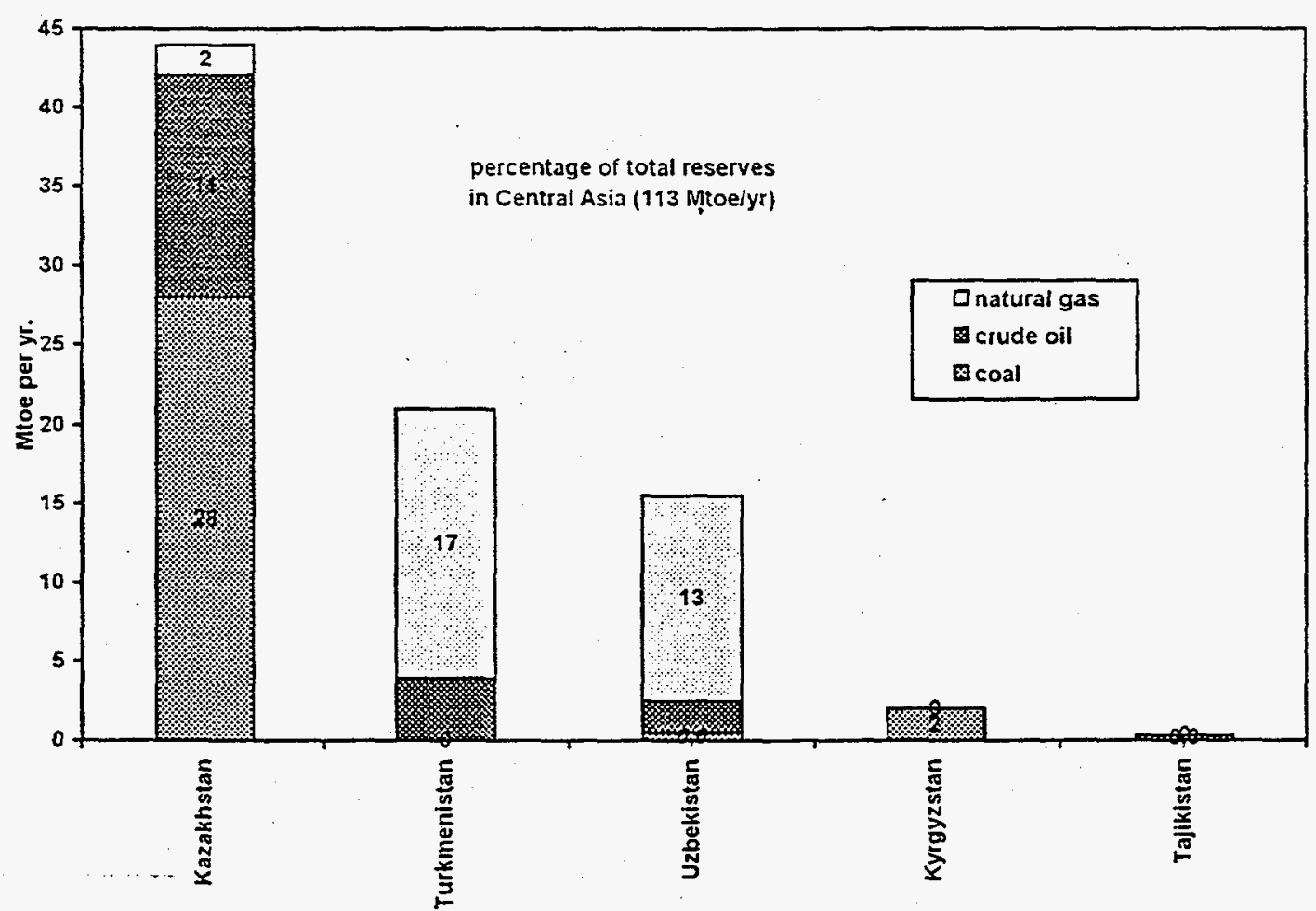

Fig.3 Primary Energy Output in 1993 


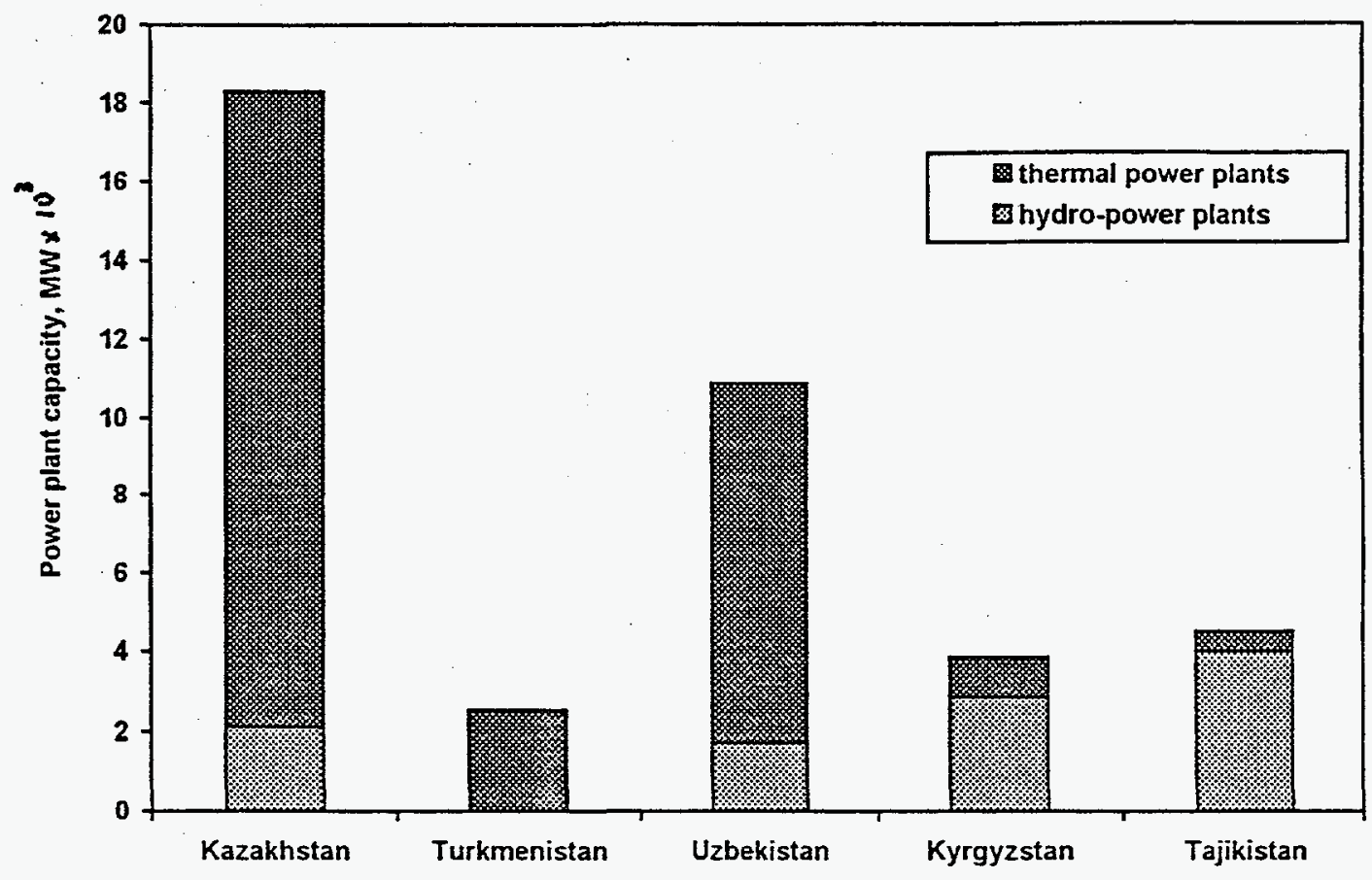

Fig.4 Power Plant Capacities of Central Asia

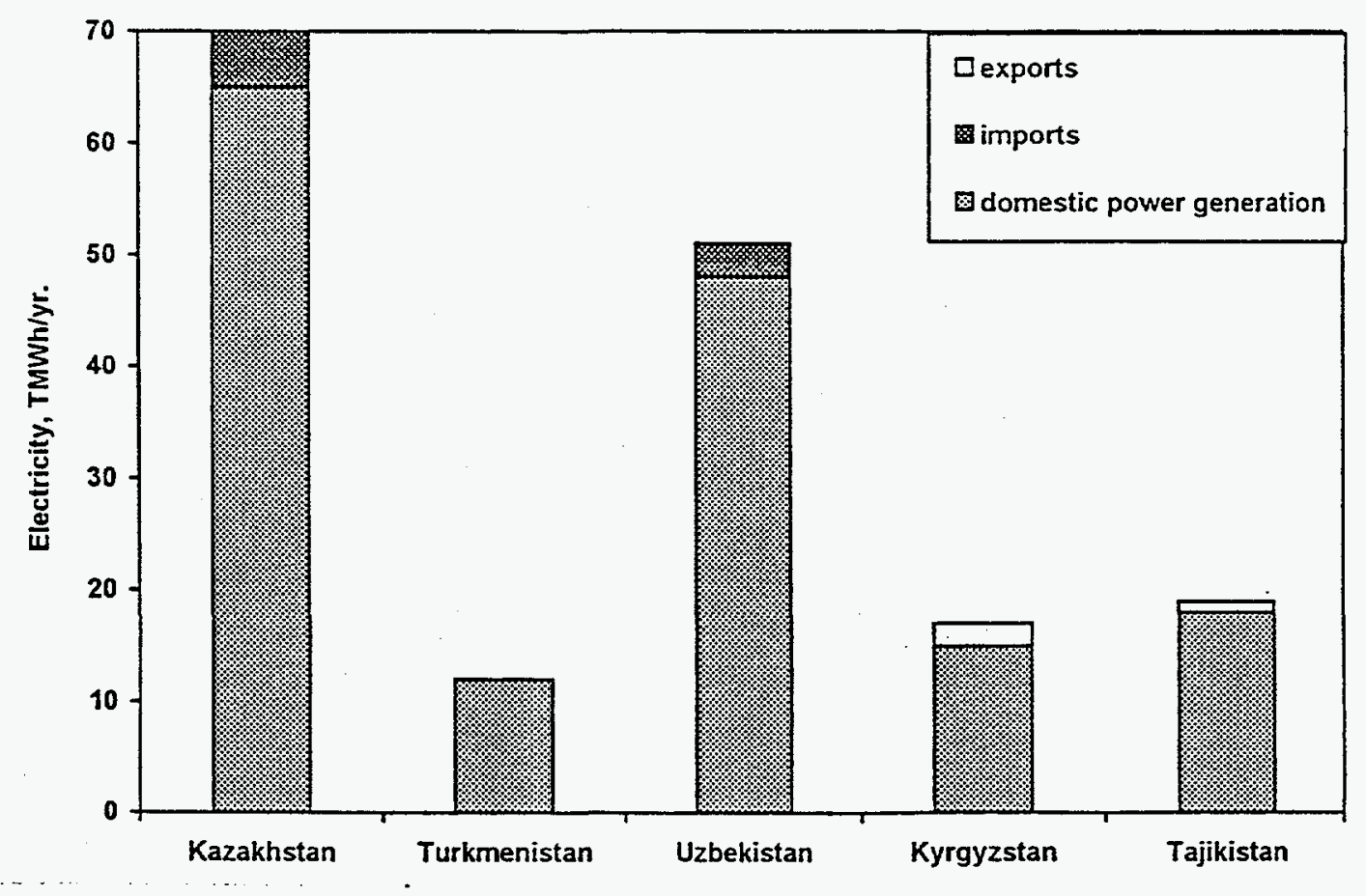

Fig.5 Electricity Production and Trade in Central Asia 


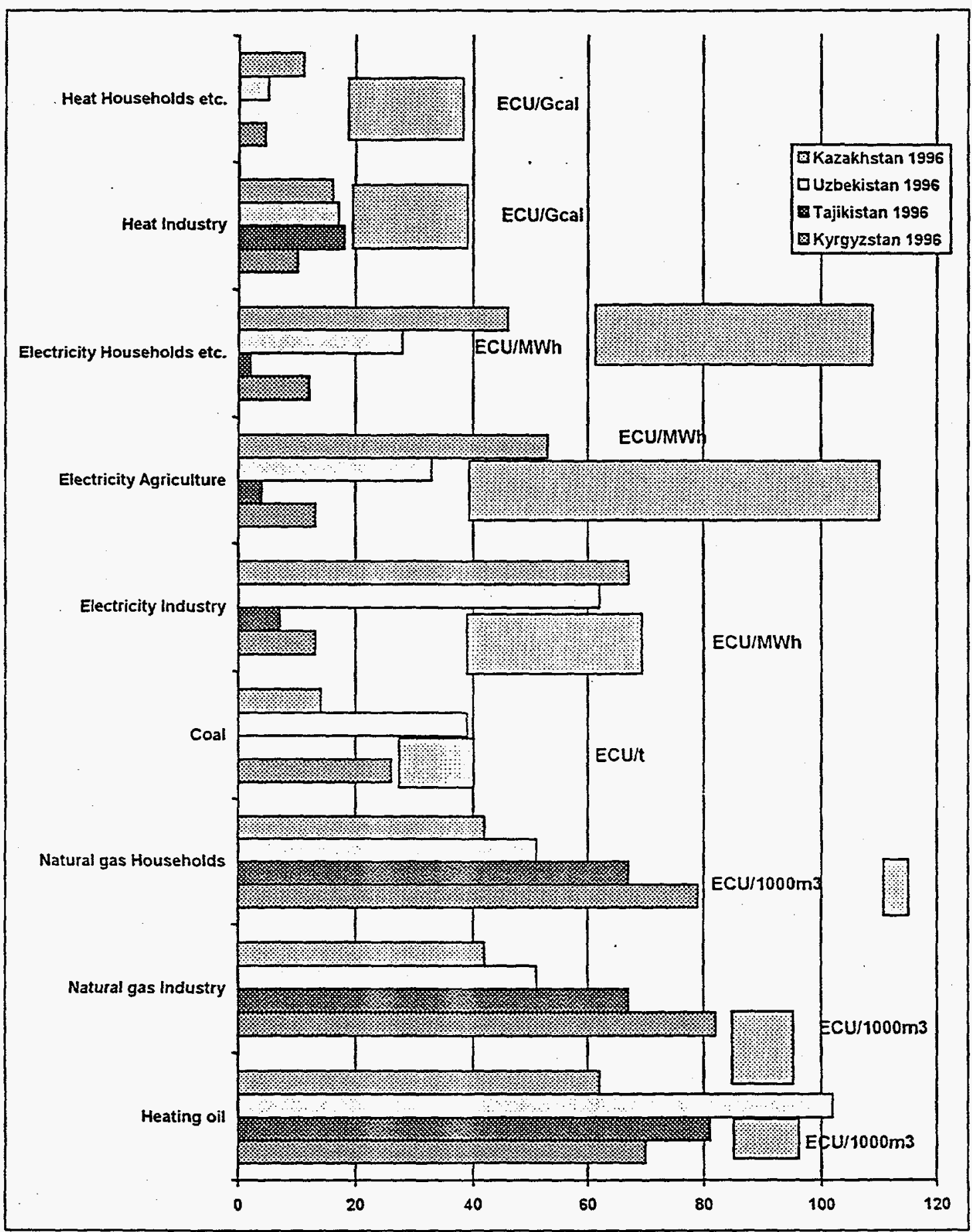

Fig. 6 Energy prices and tarifls in countries of Central Asia in 1996 in comparison to world market prices (dashed dark boxes) 
fossil fuel complex (FFC)

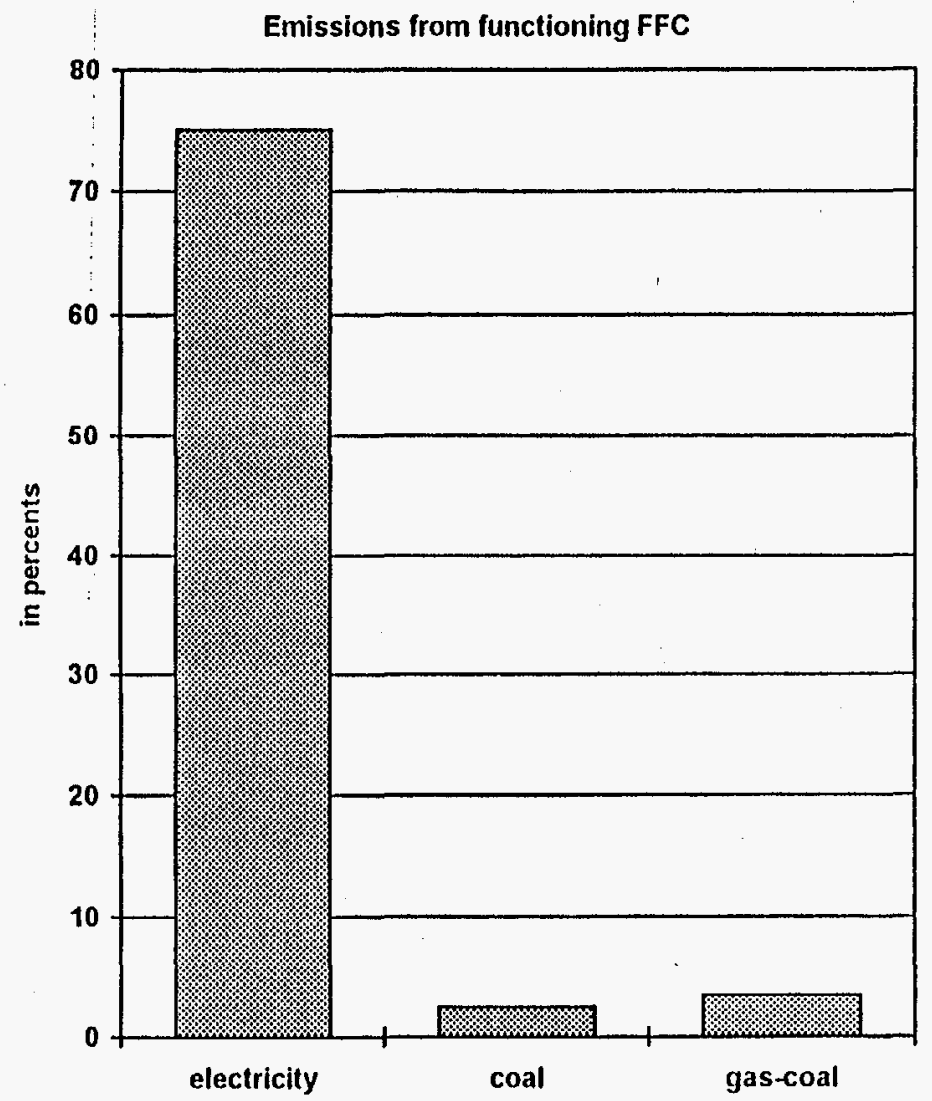

Decrease of $\mathrm{CO}_{2} \mathrm{FFC}$ utilizing biogas

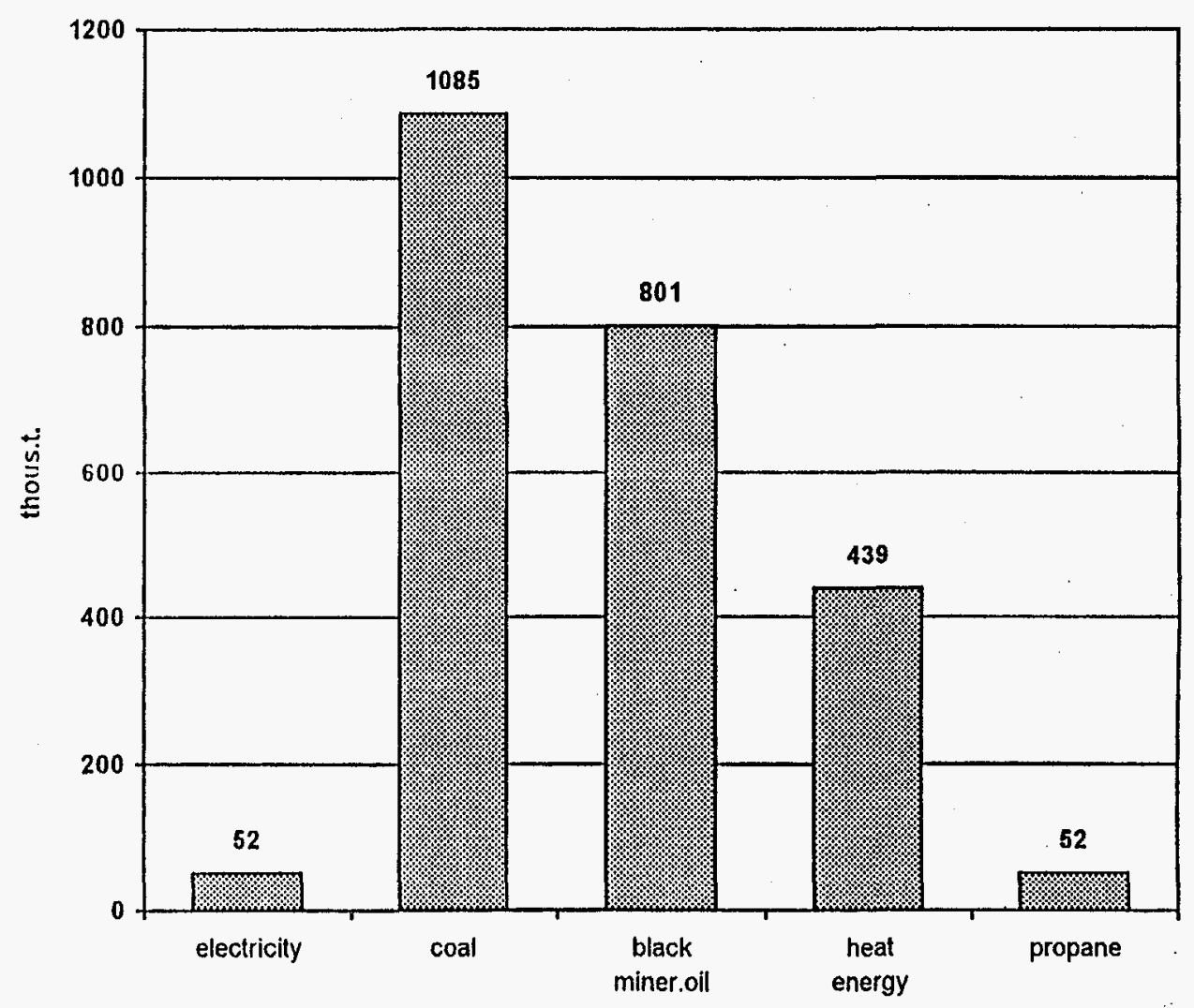

Fig.7 Environment pollution from functioning of 


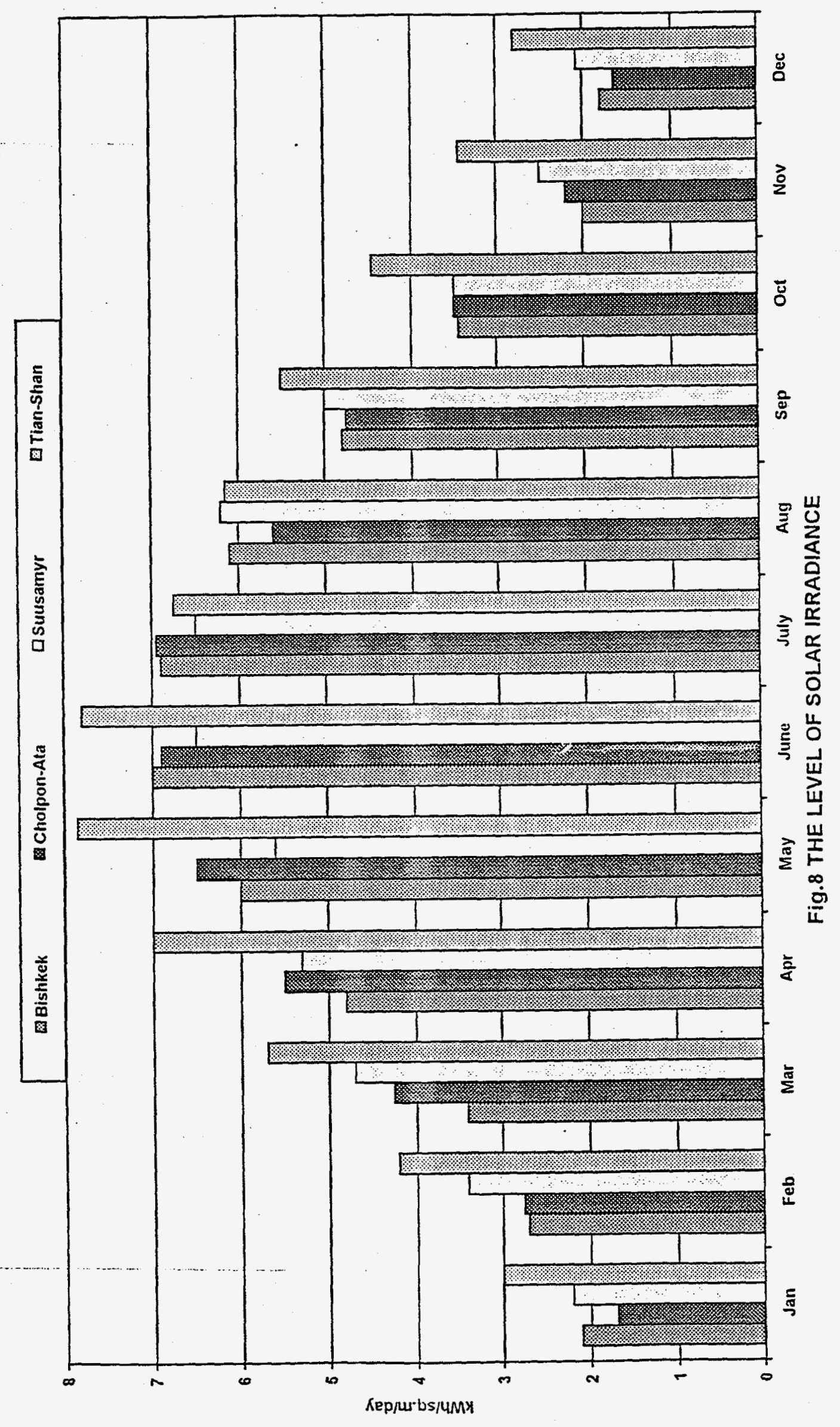




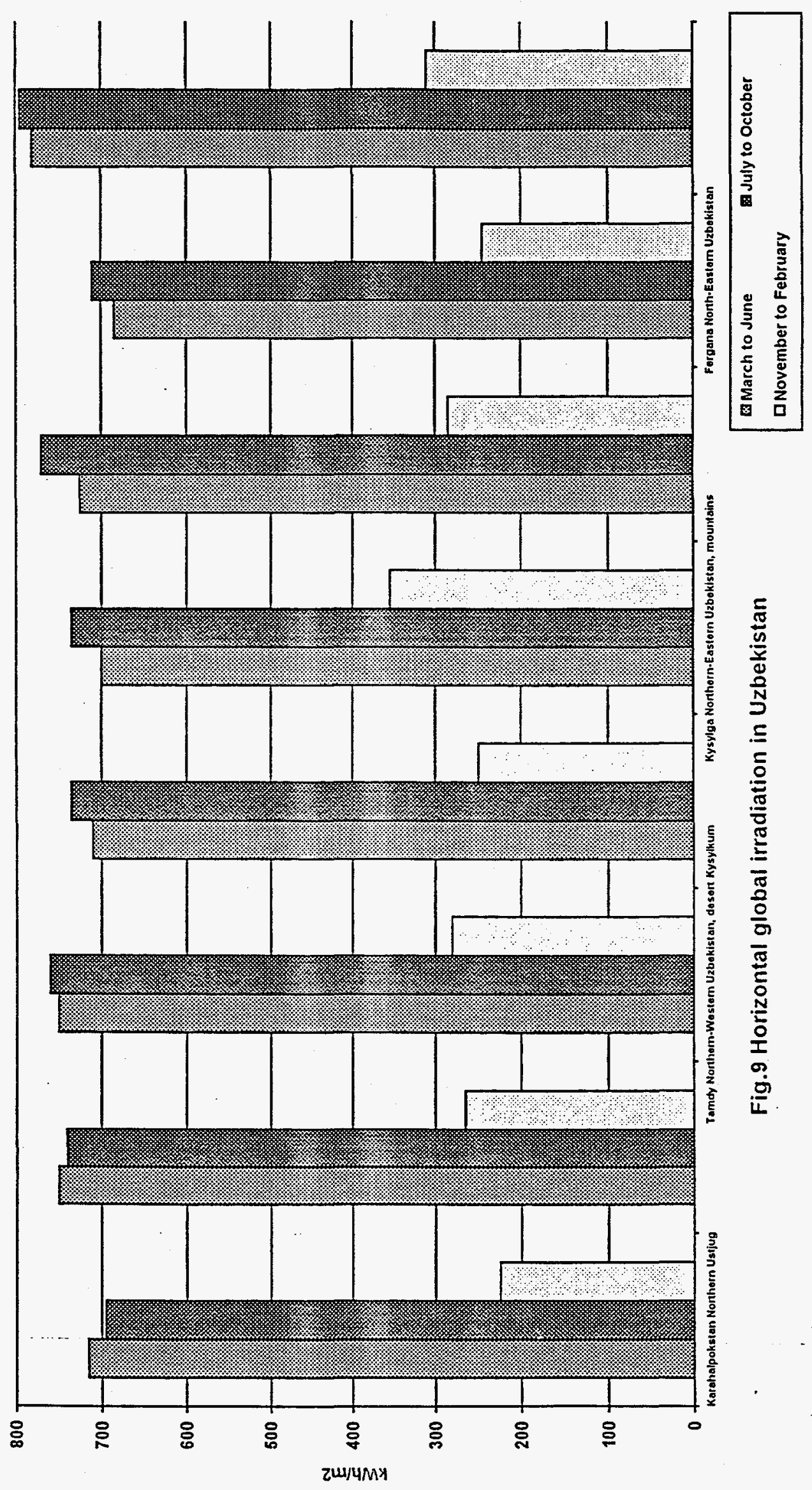




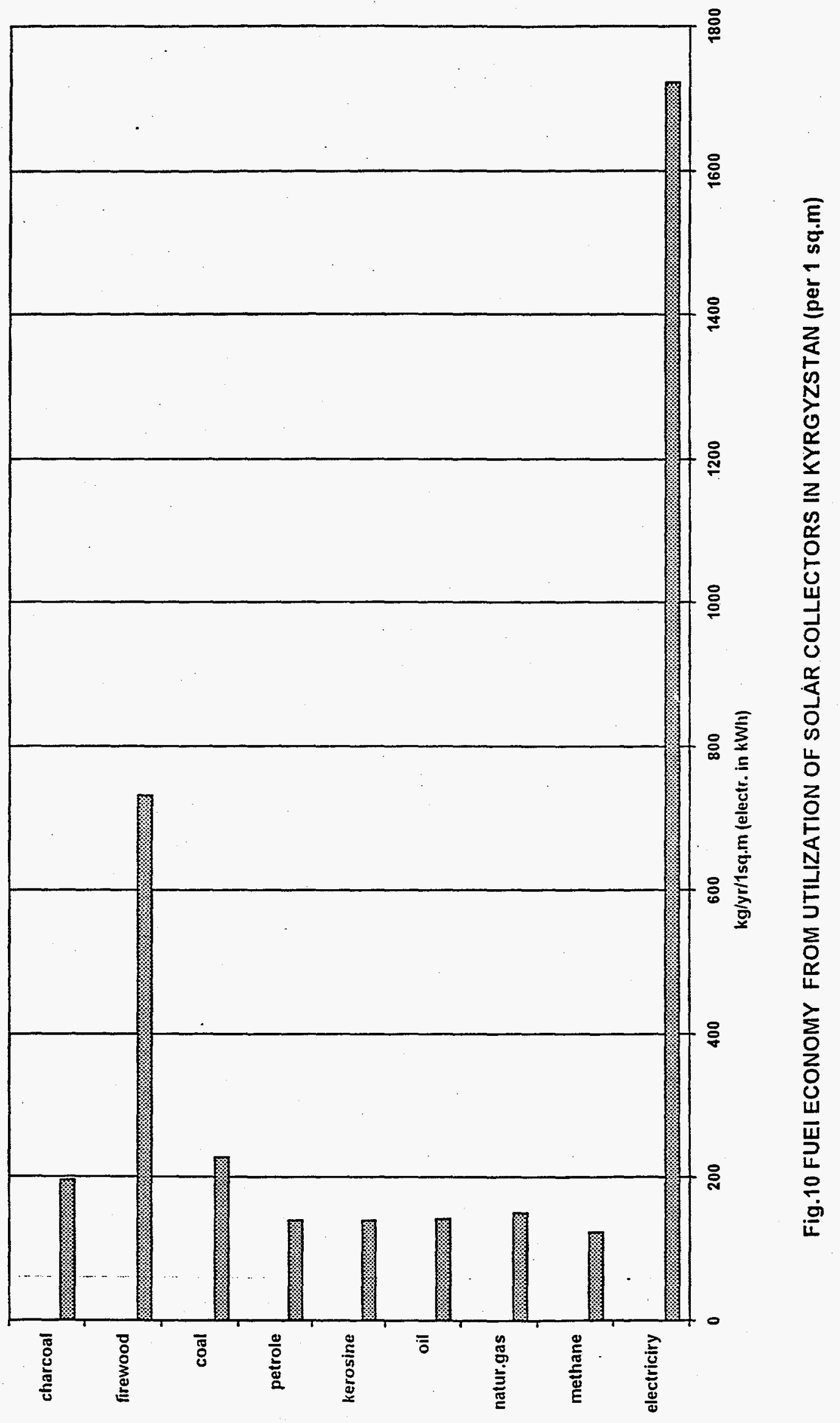




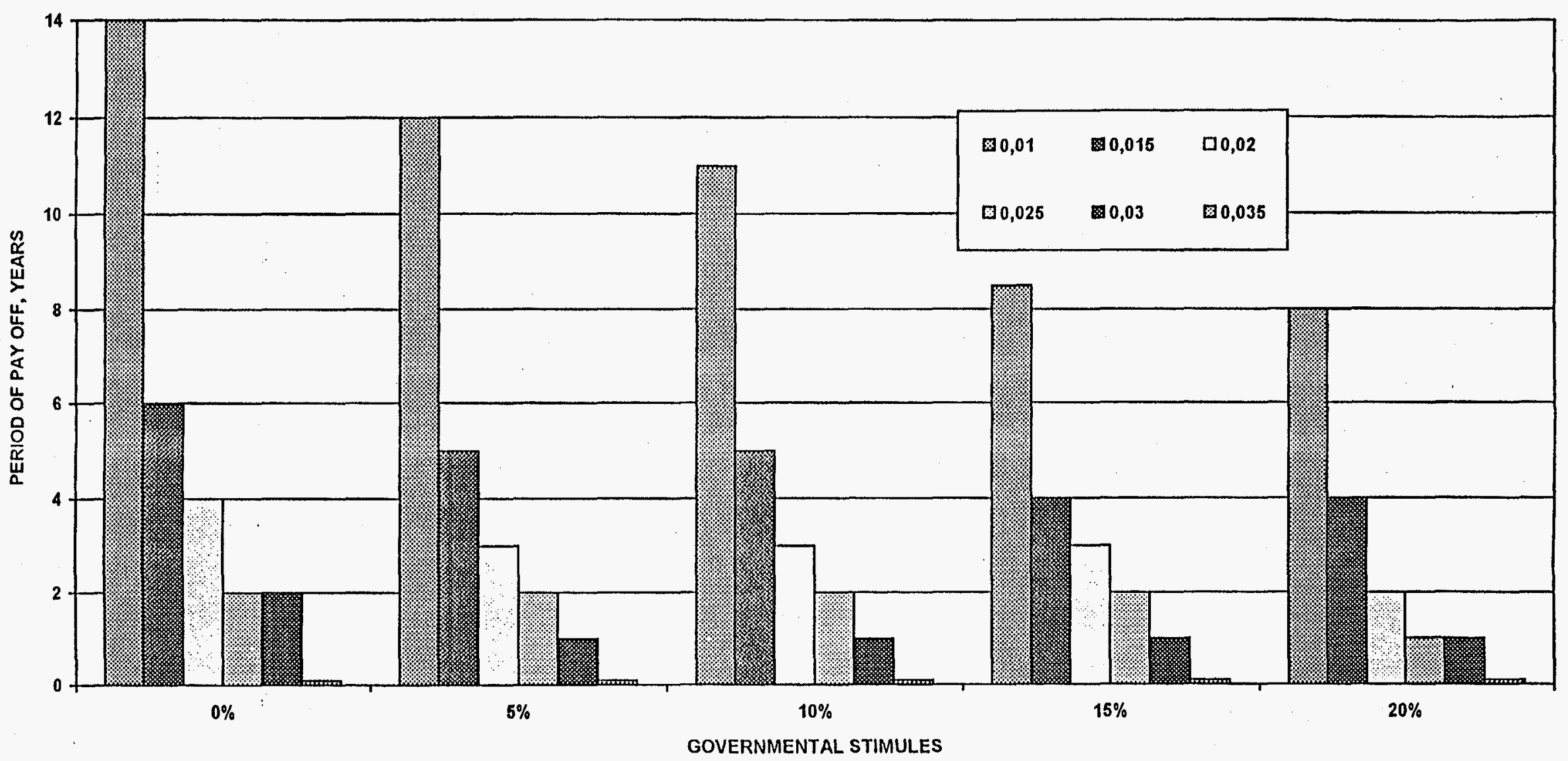

Fig.11 THE PERIOD OF PAY OFF OF DOMESTIC SOLAR WATER-HEATING INSTALLATIONS IN DEPENDENCE ON THE VALUE OF GOVERNMENTAL STIMULES 


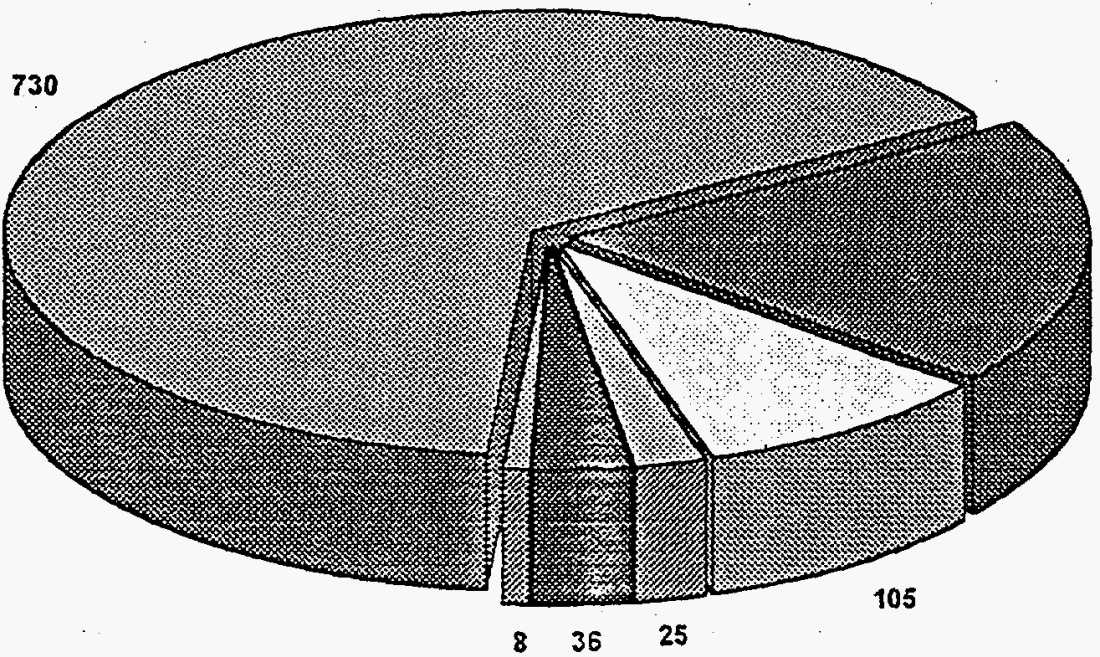

RESERVES OF BIOMASS IN KYRGYZSTAN (MLN.CUB.M/YR)

Average volume of energy saving

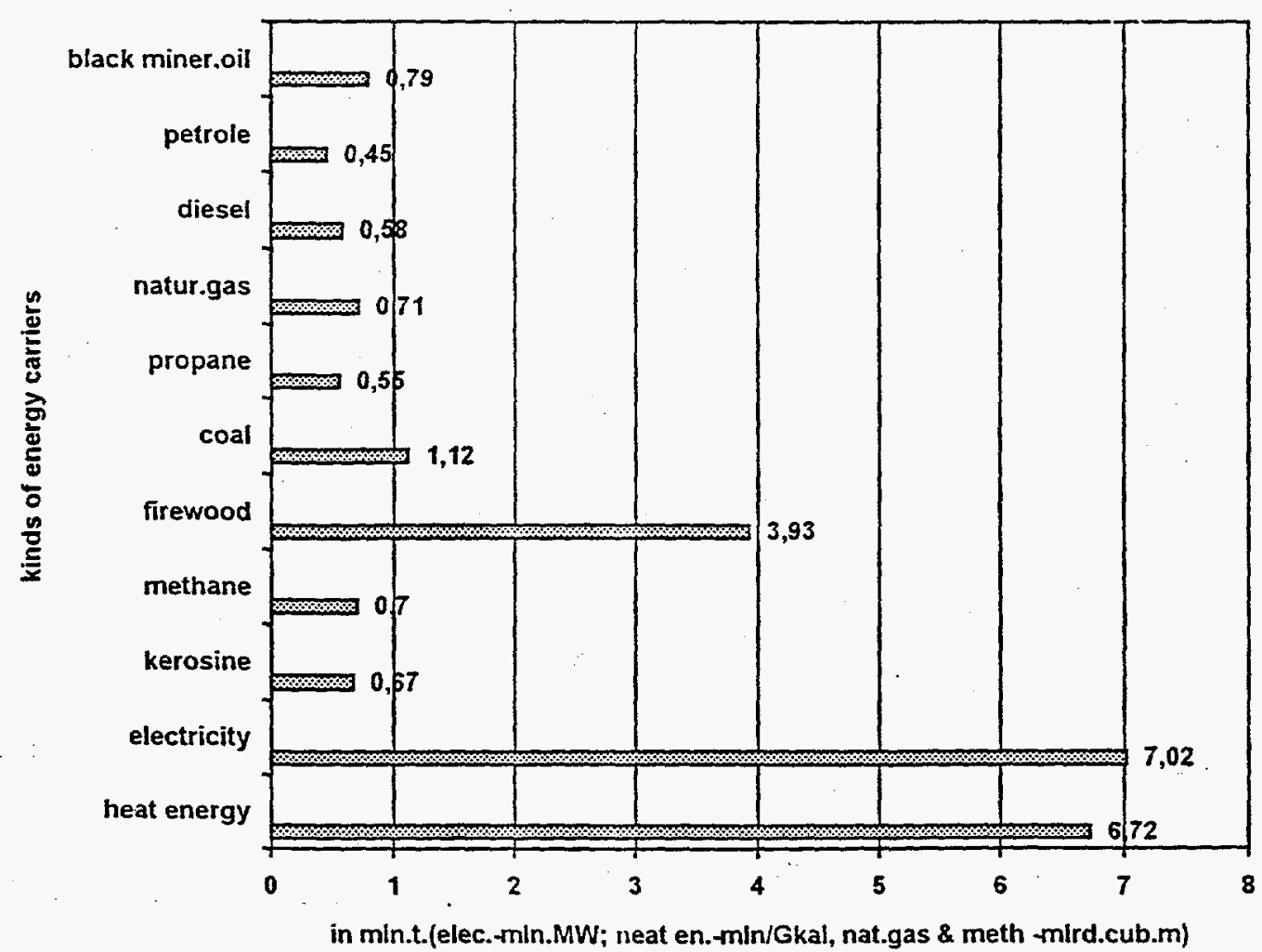

Fig.12 UTILIZATION OF BIOMASS 


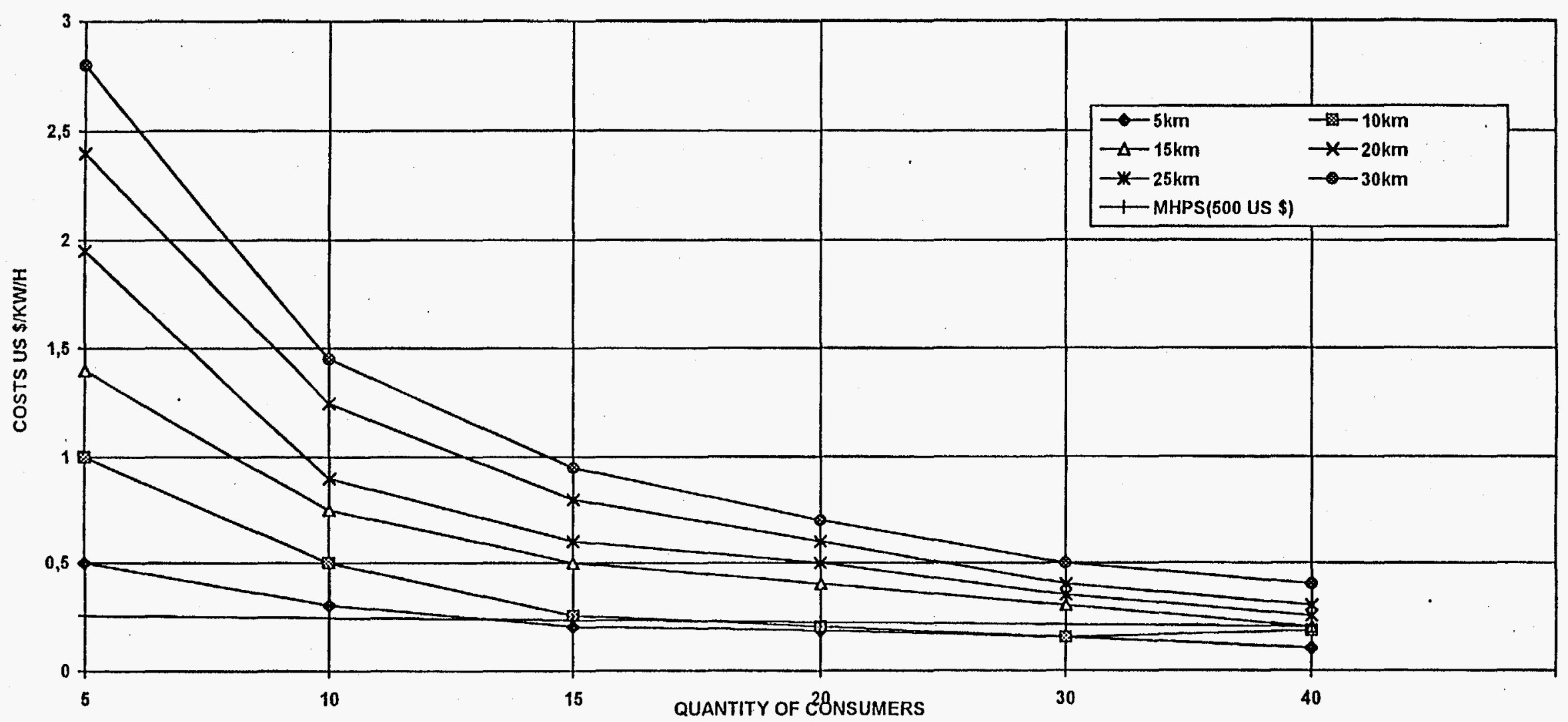

Fig.13 COSTS OF 1KW/H OF ELECTRICITY PRODUCE BY HYDROPOWER STATION AND MICROHYDROPOWER STATION IN DEPENDENCE ON THE DISTANCE TO GRID AND THE QUANTITY OF CONSUMERS 


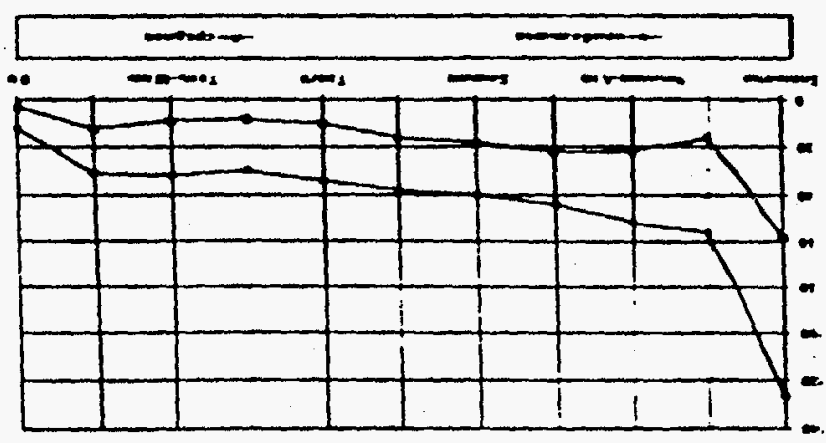

I

deas e putm alanas 4.tm

sкep jo taqumu ueall pue 7 SOI aY7
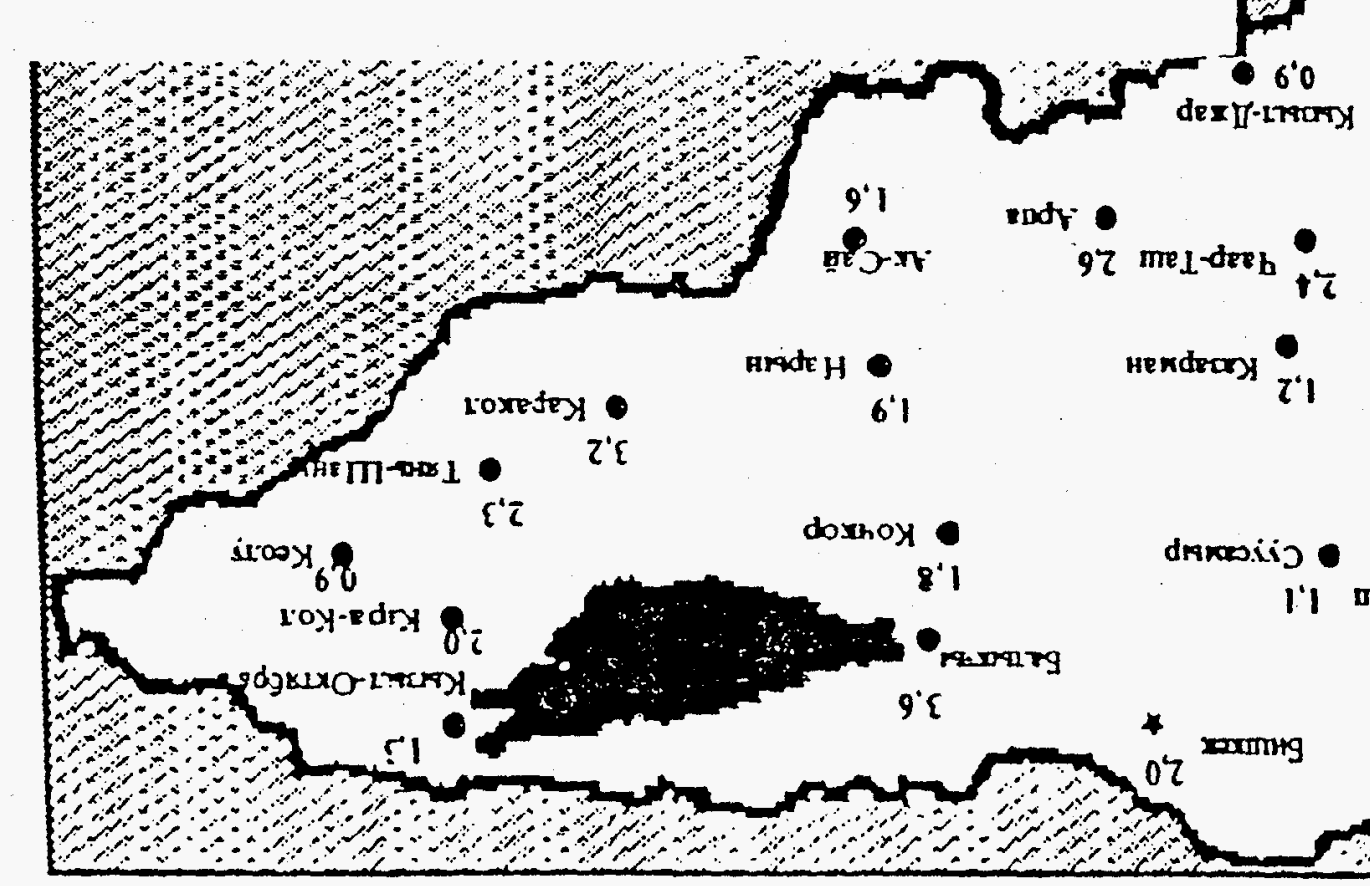

2inoswe

L'O

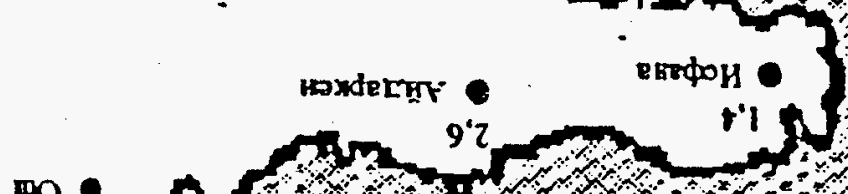

$m, 0+2$

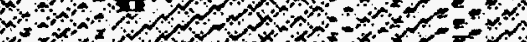

5

(1)

is

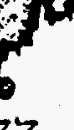

22

Lexus

$12 \operatorname{men} \cdot \times r$

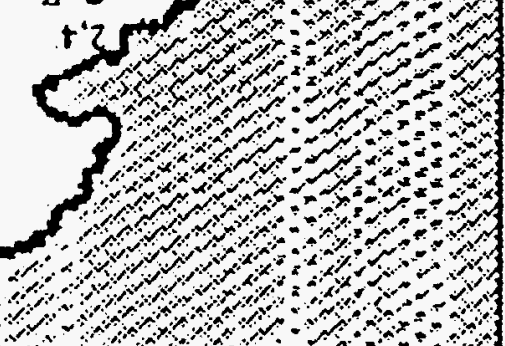

(s/u) deq0700

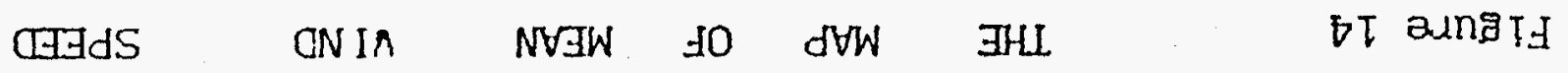



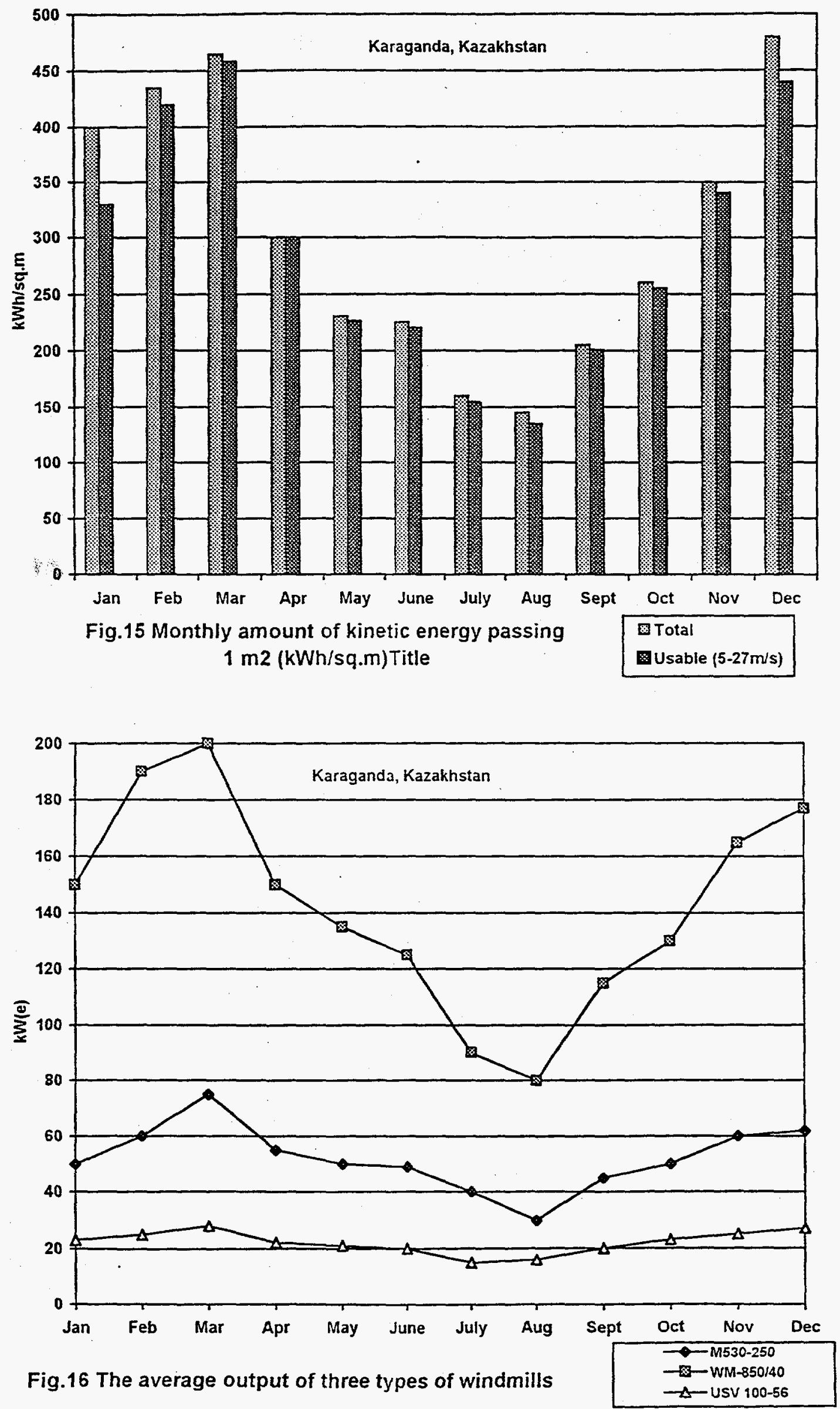